The Canadian Journal of Higher Education, Vol. XXV-3, 1995

La revue canadienne d'enseignement supérieur, Vol. XXV-3, 1995

\title{
Grade Inflation and University Admissions in Ontario: Separating Fact from Perception
}

\author{
FRANÇOIS R. CASAS ${ }^{*}$ \& DIANE E. MEAGHAN ${ }^{\dagger}$
}

\begin{abstract}
It is widely believed that high schools across Ontario have inflated grades in an attempt to help students secure admission to one of the province's universities. Universities, in turn, have raised their entrance requirements to allocate available spaces among an expanding pool of applicants. The intensified competition for higher marks has put considerable pressure on students and teachers, leading to the emergence of a number of grade-enhancing practices which potentially distort the admission process at postsecondary institutions. This paper analyzes university admission data for $1983-1993$ and concludes that (a) there has been only a moderate increase in entering marks across the system, (b) it is necessary to distinguish inflationary mark changes from changes reflecting demographic and budgetary factors such as the increase in the pool of applicants and in the available spaces, and $(c)$ different trends in entering marks for various programs are largely the result of demographic factors. It is also shown that while increases in entering marks across the university system have been modest, entering marks at individual institutions have risen more sharply, a paradox explained by the redistribution of the first-year registrants among universities.
\end{abstract}

* University of Toronto

† Seneca College

The authors gratefully acknowledge the helpful comments received from the referees and the assistance provided by Dr. D.W. Lang, Vice-Provost and Assistant VicePresident at the University of Toronto. 


\section{Résumé}

On pense communément que les écoles secondaires de l'Ontario ont gonflé les notes des élèves en vue d'aider ces derniers à se faire admettre aux universités de la province. À leur tour, ces universités ont établi des critères d'admission plus exigents afin de mieux répartir les places prévues parmi une base de candidats qui continue à s'agrandir. Les élèves et les enseignants ont donc subi l'influence de pressions considérables en raison d'une concurrence accrue dont le but est d'obtenir de meilleures notes. Ceci a mené à l'apparition de plusieurs pratiques destinées à gonfler les notes, ce qui pourrait éventuellement déformer la procédure d'admission dans les établissements post-secondaires. Les auteur examinent des données sur les admissions universitaires entre 1983 et 1993 et ils en arrivent aux conclusions suivantes: a) il n'y a eu qu'une augmentation modérée en ce qui concerne les notes d'admission dans l'ensemble des établissements post-secondaire; b) il faut faire la distinction entre les modifications qui découlent du "gonflement» des notes et celles qui correspondent aux facteurs démographiques et budgétaires, tel que l'accroissement de l'effectif étudiant et des places offertes; c) ce sont principalement des facteurs démographiques qui expliquent les diverses tendances concernant les notes d'admission aux différents programmes d'études. Les auteurs indiquent également que, même si les notes d'admission n'ont augmenté que légèrement dans l'ensemble du système universitaire, elles reflètent une augmentation plus importante dans certains établissements particuliers; ce paradoxe peut s'expliquer du fait de la répartition parmi les universités des étudiants inscrits en première année.

Students graduating from secondary schools in Ontario are admitted to the province's universities on the basis of their average mark in six Ontario Academic Courses (OACs). ${ }^{1}$ In recent years, university and school officials across the province have expressed increasing interest in and concern about a number of practices among high school students whose major purpose appears to be to raise their OAC marks and thereby boost their chances of admission at one of Ontario's sixteen universities. These practices include: ${ }^{2}$

(1) subject grazing (completing more than the six OACs required for university admission);

(2) school grazing (completing some OACs in summer, night or correspondence schools, where academic standards are perceived to be more relaxed); 
(3) repeating (failed or successfully completed OACs);

(4) sampling (dropping a course when it appears that a low mark will be achieved);

(5) slowtracking (taking less than a full course load);

(6) slumping (earning a high interim mark and subsequently exerting less effort, since university admission decisions are based on interim, not final, marks in courses taken at the time applications are submitted); ${ }^{4}$

(7) upgrading (returning to school after graduation to repeat one or more OACs or take additional ones). ${ }^{5}$

There are also many combinations and permutations of these practices. For example, a student may complete an OAC subject in a year and then repeat it the following year to earn a high interim mark. Even if the student were to fail or to drop the repeated course, only the mark earned in the first attempt would appear in the student's final record. Some students enrol in a full-year school in the fall, drop one or more courses in January and then re-enrol in the same courses in a semestered school in the Spring term to earn a high interim mark upon repeating the first part of the course. Students may also enrol in an OAC subject simultaneously in a day school and a night school, dropping either one at some point, or they may complete a course in a regular day school and then repeat it in night or summer school.

The major factor cited as an explanation for these practices is an alleged inflation of high school marks that has compelled universities to raise their admission standards in order to ration the existing spaces among applicants, thereby further inflaming the competition for higher marks. Rumours abound that a certain faculty or university has dramatically raised its minimum cutoff point, with university officials themselves lending credibility to such rumours. For example, B.G. Granger (1994), Wilfrid Laurier University's Manager of Admissions, recently referred to "upward-spiralling admission averages."

Trying to assign blame in these circumstances would be as useful as determining whether the chicken came before the egg. The strategic behaviour revealed by these grade-enhancing practices raises a number of issues around the efficiency and equity of the current university admission system, as well as having significant pedagogical and budgetary implications for Ontario high schools (Casas, 1994). However, the incidence and impact of these practices need to be documented and analyzed before possible remedies can be discussed. For example, there have been calls for the use of a standardized test such as the Scholastic Aptitude Test (SAT) as part of the university admission process on 
the grounds that high school marks are no longer good predictors of performance at the postsecondary level. Such calls overlook the lack of evidence that the use of standardized tests might improve the selection process; indeed, the empirical evidence points to the fact that these tests are a poorer performance predictor than high school marks, ${ }^{7}$ in addition to the cost of these tests, the high probability of cultural, racial and gender biases inherent in such tests and the potential for distorting the school curriculum as testing begins to drive instruction. ${ }^{8}$

It has also been suggested that universities should be provided with more information about applicants' high school records, although there are no data as yet showing to what extent practices such as repeating or grazing inflate the average high school mark of university applicants and to what extent such practices have a differential effect on students' average marks as opposed to raising most applicants' marks equiproportionately. A case can be made that it would be unfair to deny a student the opportunity to repeat an $\mathrm{OAC}$ subject or to discount the performance achieved in a repeated subject, although it remains to be established whether these opportunities to improve one's marks are available to all students on an equitable basis. ${ }^{9}$ These and many other issues need to be fully aired before school, university or Ministry officials can begin generating solutions for problems whose very nature and impact are, by and large, poorly understood.

The objective of this paper is to initiate a discussion of these issues by examining the validity of what has become accepted as conventional wisdom, namely, that there has indeed occurred a significant escalation in the average marks needed to be admitted to Ontario's universities. For if this "fact" has little substance, high school students would have been relying on inaccurate information in making their choices of OAC subjects. ${ }^{10}$ By increasing the pressure on these students to raise their marks, rumours of grade hyperinflation may be contributing to the spread of the grade-enhancing practices described earlier. This study of grade inflation is situated in the broader framework of an empirical investigation of these grade-enhancing practices and our ultimate objective is to research how such practices affect the selection of applicants by postsecondary institutions and what problems they raise for our school system. To the extent that some inflation has occurred, it is necessary to search for its sources as well as to explore whether its impact is widespread or whether it affects various segments of the student population in a differential manner.

It is our contention that excessive attention had been focused on the lowest average OAC (or cutoff) mark for students admitted to particular university programs at various Ontario universities. It is highly unusual in describing any distribution to single out its lowest value while ignoring more conventional 
measures of location and dispersion. This kind of information has little value as an index of how difficult it is to gain admission into a program since all but a handful of admitted applicants have higher averages. For example, it is possible to construct a hypothetical scenario in which a university receives applications from six candidates whose average marks are $90,85,80,75,70$ and 65 . If that university admits five students, the cutoff mark would be $70 \%$. In the following year, another six students may apply, with averages of $90,85,80,75,74$ and 65 , forcing the university to raise its cutoff mark by a dramatic 4 percentage points, even though the median mark for admitted students is unchanged (at 80 ) and the mean entering mark rises moderately from 80.0 to 80.8 . Even if such an occurrence is somewhat implausible, concentrating on the lowest mark for a group of students admitted to a program is a poor measure of how difficult it is to secure admission to that program.

We also intend to demonstrate that higher university entrance standards do not necessarily result from grade inflation at the high school level but that the explanation may lie elsewhere. There is a lack of understanding of how the university admission process operates and, in particular, how changes in the size of the student pool may interact with changing average high school marks and changing intake levels by universities to determine the widely quoted criterion of minimum admission marks. This paper provides a theoretical framework to separate demographic and economic factors which affect admission standards from other factors, including grade inflation at the secondary school level. Wegman (1987) has noted that grade inflation calls into question academic standards and potentially reduces the value of degrees conferred, while Bromley, Crow and Gibson (1978) have pointed out that changing grade distributions can significantly impair the reinforcement/motivation and the selectivity functions of grades. It is therefore important to establish the magnitude of this problem and its causes.

The subject of grade inflation at the secondary school level and its potential repercussions on postsecondary institutions has received relatively little attention. Queen's University sociologists King and Peirt (1994) recently studied marks awarded Ontario's high school students in 1990-91, in addition to surveying students, teachers and parents at a few schools. While much useful information emerges from their study in terms of patterns of marks across different grade levels, subjects and genders, ${ }^{11}$ the data base employed in the study was not adequate for an analysis of marks over time or to document grade-enhancing practices. In the United States, discussion of grade inflation has tended to revolve around marks at the university level, particularly in the $1970 \mathrm{~s}$, with 
much concern expressed for the resulting devaluation of degrees. ${ }^{12}$ Much controversy has also surrounded the significance of standardized test scores and of changes in these scores over time (Bracey, 1991).

\section{University Entering Averages: The Macro Picture}

Figure 1A shows the distribution of entering averages for secondary school registrants from 1983 to 1993 . These are first-year university students who were registered as full-time day students at an Ontario secondary school in their preuniversity year. Excluded are those registrants who, at the time of application, had fewer than six OACs (including subjects currently taken for which interim marks are used) and who took summer courses, sending their marks directly to the universities in August. Also excluded are the so-called regular students, comprising students enrolled in a preliminary year program at an Ontario university, those who completed high school in a prior year or who graduated from a correspondence, night, out-of-province or out-of-country school, and those who transferred from a College of Applied Arts and Technology, a Quebec Collège d'Enseignement Général et Professionnel (CGEP), or an out-ofprovince or foreign college or university. ${ }^{13}$

Entering marks have changed moderately over this period with the largest increases occurring in the lower percentiles, not unlike the hypothetical example described earlier. Since there are usually a few students with low averages admitted on special grounds, it is reasonable to disregard the relatively small bottom group of registrants and use the tenth percentile as the effective cutoff. ${ }^{14}$ In 1983 , $90 \%$ of all registered applicants had an entering average of 65 or better; by 1993 , this had risen to 69. Earnshaw (1994) noted that this grade inflation occurred across all percentiles; however, it was less pronounced at the upper end of the distribution of entering averages: the 75th percentile only rose by 2 (from 82 to 84 ) and has not increased since 1989. In other words, there was a compression of the distribution of entering averages, with the tail end of that distribution being eroded at a faster rate than the rise in the central value. The median entering average rose by 3 (from 76 to 79 ), while the mean rose by a more modest 2.6 (from 76.2 to 78.8 ) with a concomitant reduction in the dispersion of marks as the interquartile range shrank from 12 to 10 . Figure $1 \mathrm{~B}$ shows the frequency distribution of entering averages in three selected years during this period. The unexpectedly large proportion of registrants with an entering average of $80 \%$ reflects the widespread practice of adjusting marks for students whose average is close to that standard in order that they may qualify for the designation as 
Figure 1A

Distribution of Entering Averages of Secondary School Registrants, 1983-1993.

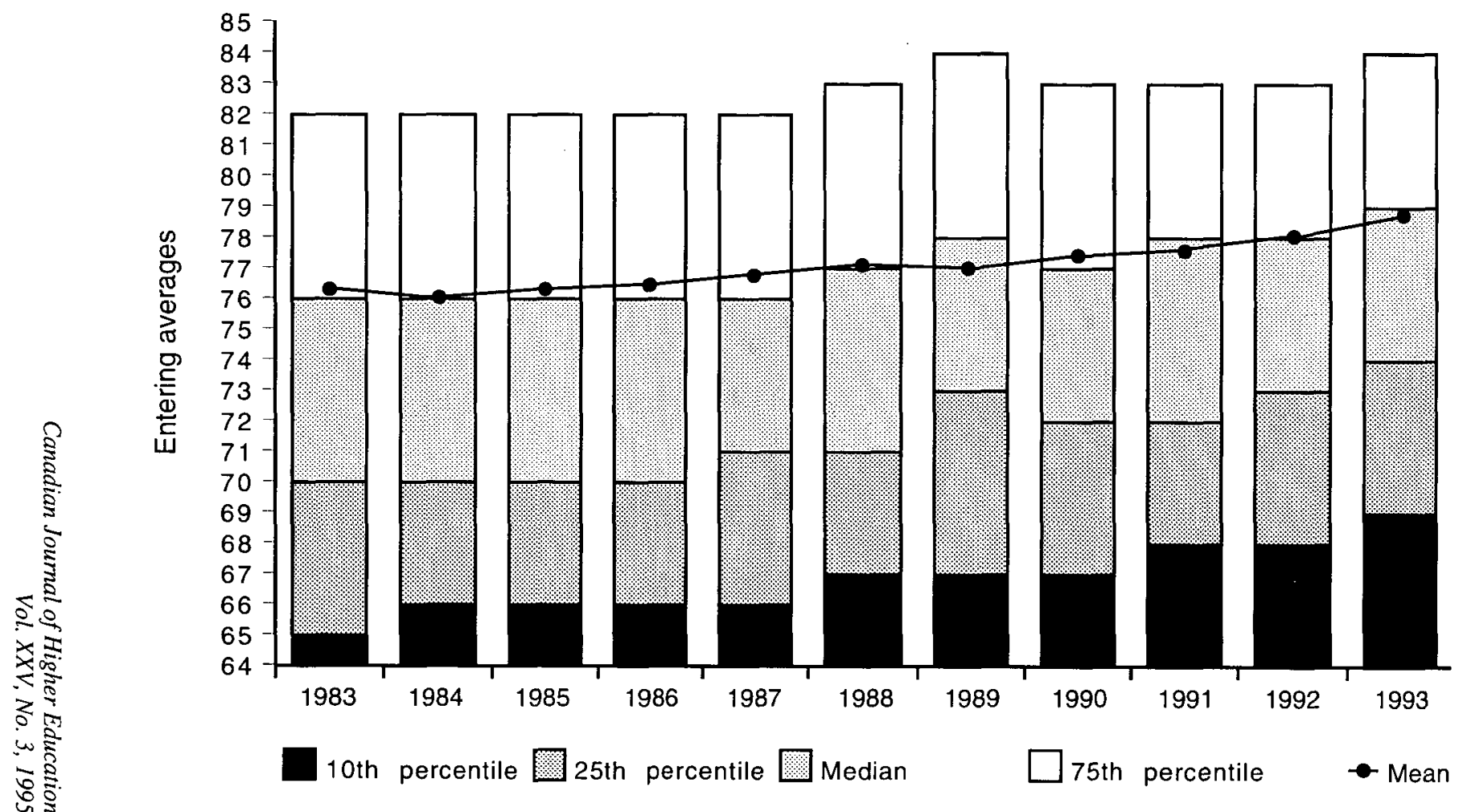




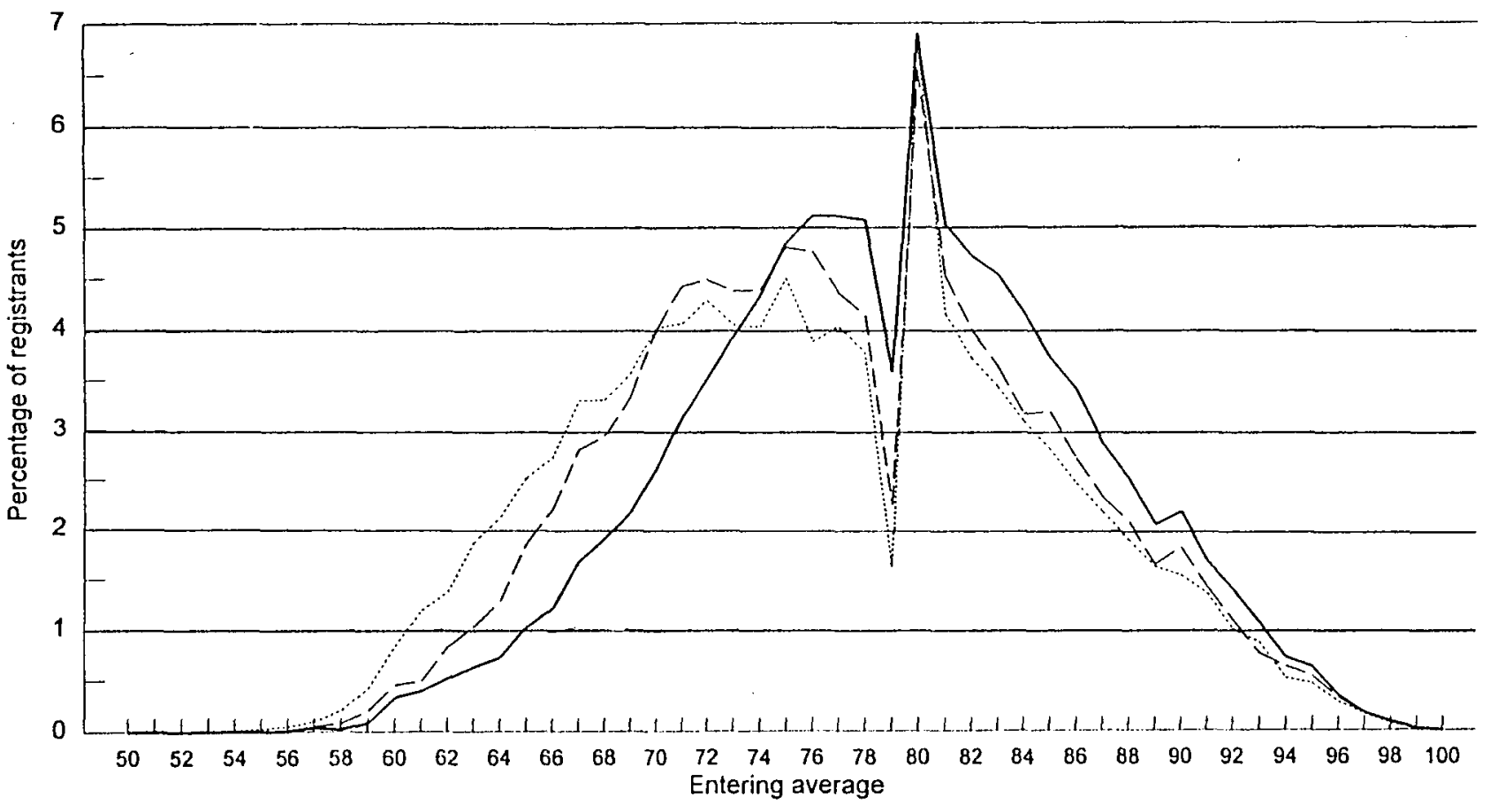


Ontario Scholars. While conferring this title no longer carries a monetary prize, it retains a traditional value among high school students.

Comparing cutoff or median entering averages for successive cohorts of first-year university registrants, however, is not an adequate basis for estimating the extent of grade inflation, for such a comparison fails to isolate the impact of three distinct factors which affect these indices: (a) the size of the pool of applicants, (b) the average marks of these applicants and (c) the number of admitted students. While increases in the first two tend to raise the cutoff and median entering marks, changes in the third one have the opposite effect. In an attempt to isolate these various factors, Figure $1 \mathrm{C}$ shows the cumulative distribution of entering marks in 1983 and 1993. Each curve displays the number of first year registrants who had at least the entering average indicated on the horizontal axis. Figure $1 \mathrm{C}$ also includes an "adjusted" 1983 curve showing what the cumulative distribution of entering marks in 1983 would have been if the pool of applicants that year had the same distribution of marks as the 1993 pool..$^{15}$

Examination of Figure $1 \mathrm{C}$ reveals that:

[a] If the number of applicants and the number of university spaces had remained constant between 1983 and 1993, the median entering average mark would have risen from 76 to $80\left(\mathrm{M}_{1983}\right.$ to $\mathrm{M}_{\mathrm{a}}$ in Figure 1C). We can therefore state that across all subjects high school marks rose by 4 percentage points, not 3 points as a comparison between the median entering marks in 1983 and 1993 would suggest. Under the same circumstances the cutoff mark would have risen by 6 percentage points, from 65 to 71 $\left(C_{1983}\right.$ to $C_{a}$ in Figure 1C).

[b] The increase in the number of applicants from 47,902 to 59,275 inflated the median entering mark by an additional 1 percentage point from 80 to $81\left(\mathrm{M}_{\mathrm{a}}\right.$ to $\mathrm{M}_{\mathrm{b}}$ in Figure $\left.1 \mathrm{C}\right)$ and the cutoff mark by another 4 points from 71 to $75\left(\mathrm{C}_{\mathrm{a}}\right.$ to $\left.\mathrm{C}_{\mathrm{b}}\right)$.

[c] Finally, the rise in the number of spaces for first-year students reduced the median entering mark by 2 percentage points from 81 to $79\left(\mathrm{M}_{\mathrm{b}}\right.$ to $M_{1993}$ in Figure 1C) and the cutoff mark by 6 points from 75 to $69\left(C_{b}\right.$ to $\left.C_{1993}\right)$.

These results are summarized in Table 1. 


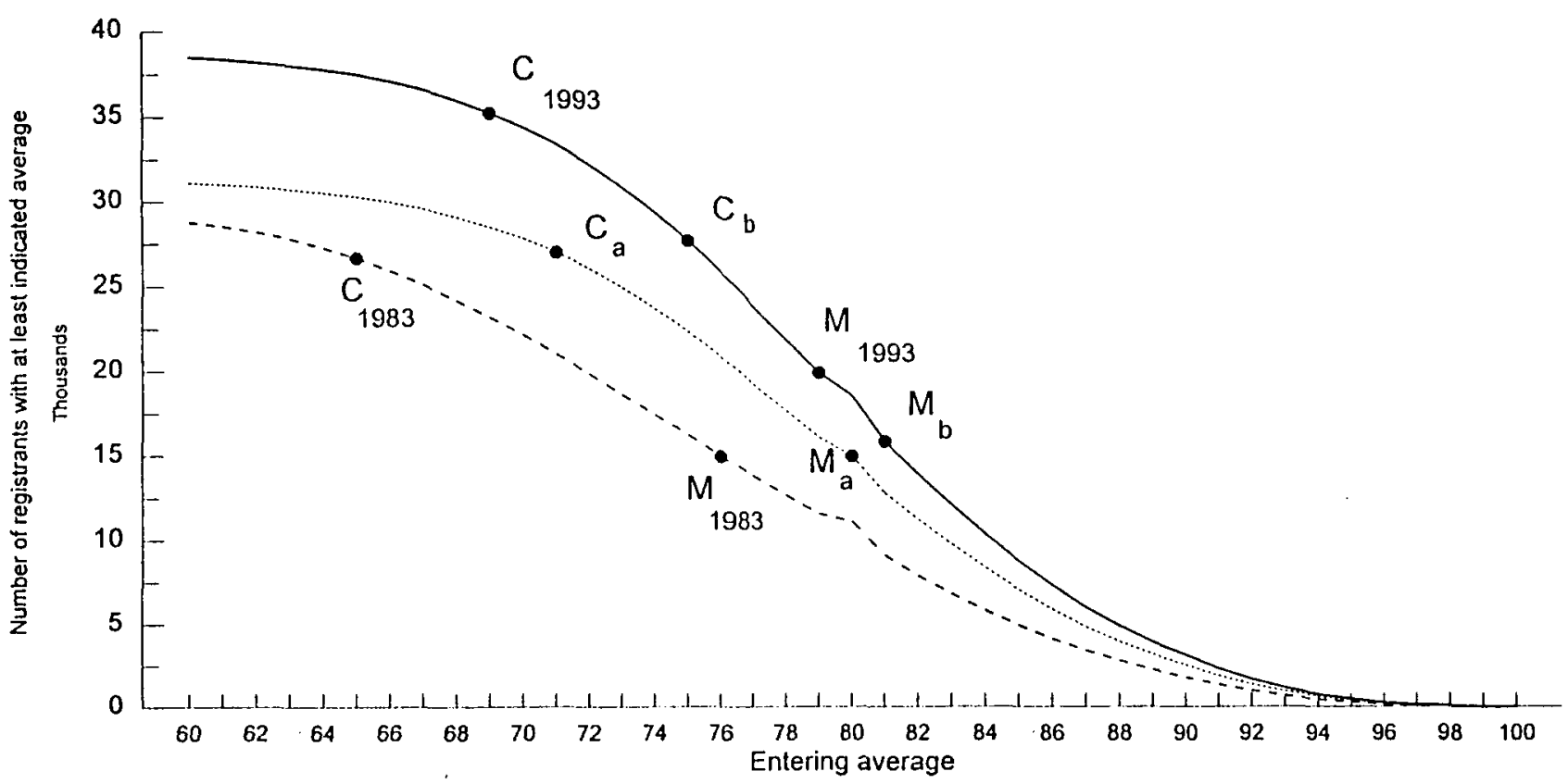


Table 1

\begin{tabular}{lcccc}
\hline Change in: & $\begin{array}{c}\text { Due to grade } \\
\text { inflation }\end{array}$ & $\begin{array}{c}\text { Due to larger pool } \\
\text { of applicants }\end{array}$ & $\begin{array}{c}\text { Due to larger } \\
\text { university intake }\end{array}$ & $\begin{array}{c}\text { Net } \\
\text { change }\end{array}$ \\
\hline Cutoff entering mark & +6 & +4 & -6 & +4 \\
Median entering mark & +4 & +1 & -2 & +3 \\
\hline
\end{tabular}

\section{Entering Averages by Program and by University}

The rise in entering averages was not evenly distributed among all programs. Figures $2 \mathrm{~A}$ and $2 \mathrm{~B}$ show the cutoff (tenth percentile) and median entering averages for the six largest programs which together account for nearly 90 percent of all secondary school registrants. The most dramatic inflation occurred in physical education with the median entering average rising from 71 in 1983 to 78 in 1993 and with an equally large increase in the 10th percentile (from 64 to 71). This occurred despite the higher-than-average expansion in the number of secondary school registrants in this program, $39.7 \%$ compared with $32.9 \%$ for all programs combined. However, it should be noted that the number of applications for this program also expanded much faster $(46.4 \%)$ than the number of applicants (23.7\%) and applications (27.8\%) across all programs. ${ }^{16}$ Clearly, this was a case of expansion in demand outstripping the growth in supply, resulting in an increase in the "price" of admission.

Perhaps more surprising is the fact that the median entering average in engineering - while higher than in the other five major programs - remained unchanged during the period covered by the data. Just as (or perhaps more) surprising is the fact that the 10th percentile declined from 75 to 73 . Some of this may be linked to the inclusion after 1989 of Ryerson Polytechnic Institute (elevated to university status in 1993) with a relatively large engineering program (seventh among the 12 such programs in the province in terms of enrolment). However, it is also the case that admissions into engineering expanded by $30.4 \%$ whereas applications only rose by $4.3 \%$. A similar explanation applies to the decline in the cutoff and median entering marks in nursing with admissions rising by $22.4 \%$ while applications declined by $40.5 \%$. Of the remaining three major programs, commerce was the most stable in terms of entering averages, although in each case registrations rose more than applications: $43.9 \%$ vs. $32.4 \%$ in arts, $13.4 \%$ vs $4.6 \%$ in science and $42.6 \%$ vs. $16.8 \%$ in commerce. ${ }^{17}$ 


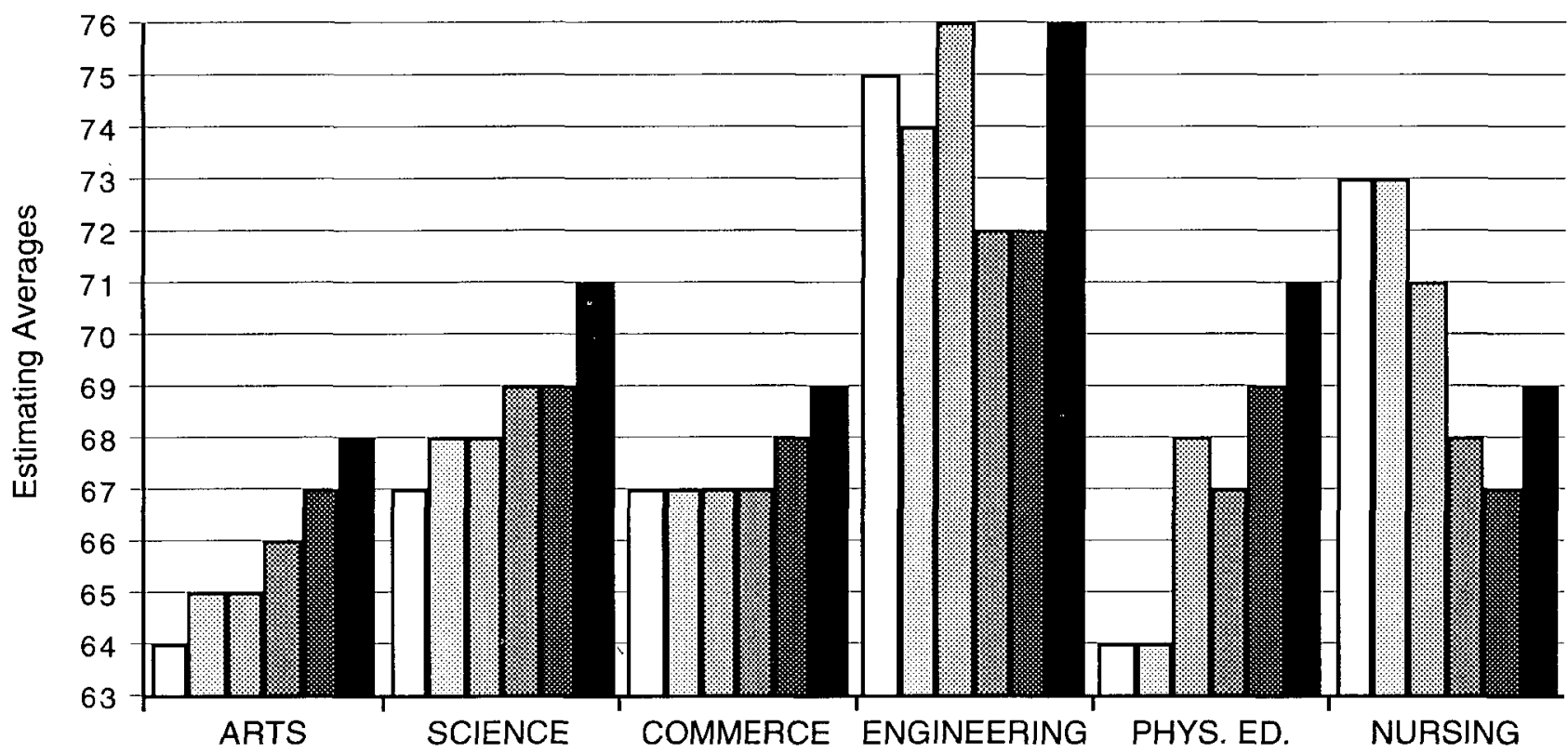

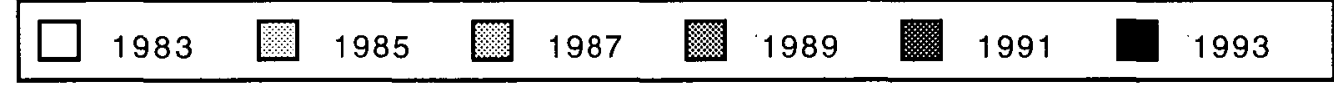


Figure 2B

Median Entering Averages in Major Programs, 1983-1993.

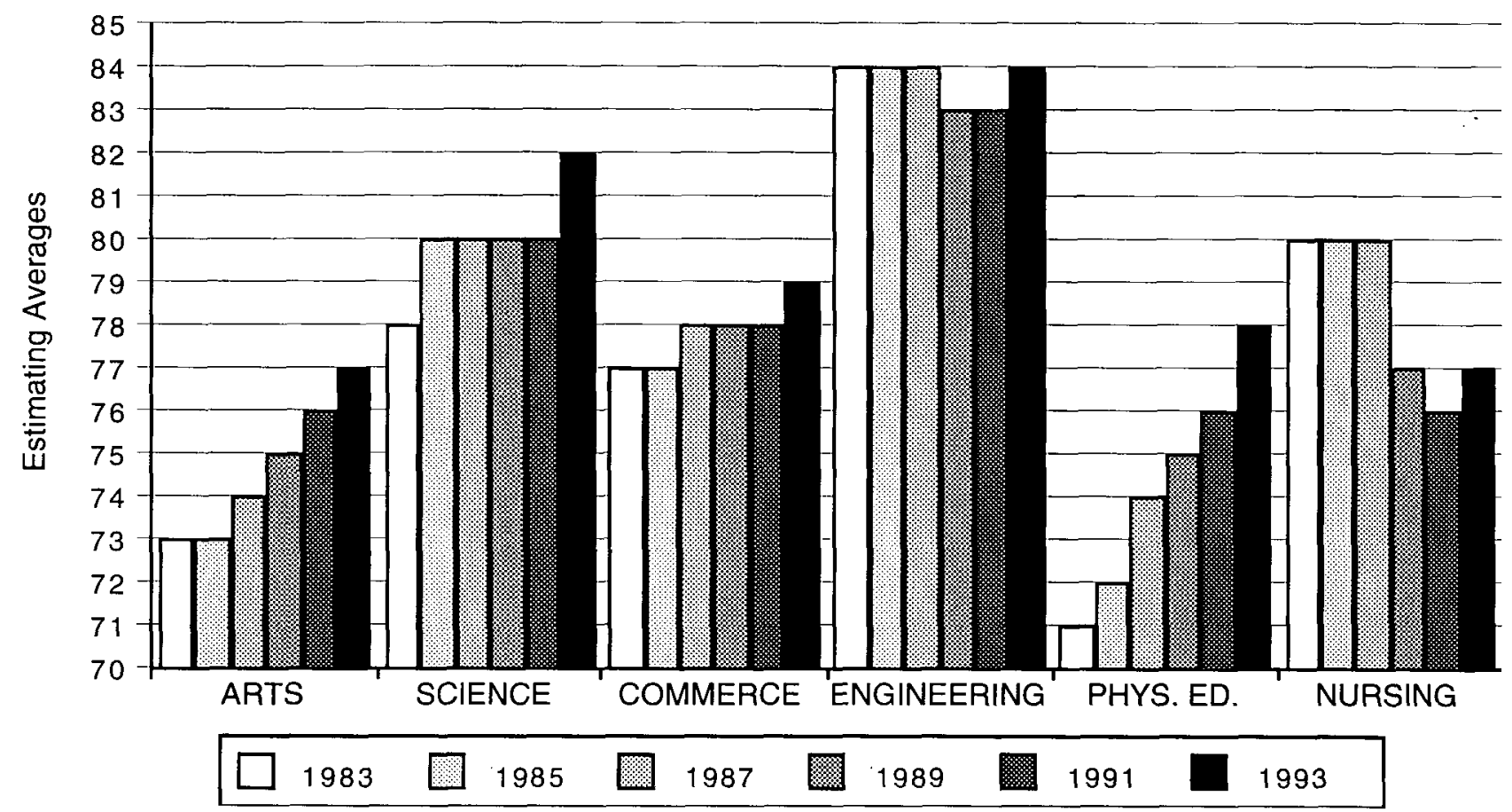


In order to isolate the impact of changes in the number of applications and in the number of admissions on the median entering mark, we ran an Ordinary Least Squares regression which yielded the following equation (with $t$-values in parentheses) for the 1984-1993 interval:

$$
\mathrm{PCM}=\underset{(87.464)}{0.064}+\underset{(4.487)}{0.155}(\mathrm{PCA}-\mathrm{PCR}), \quad \mathrm{R}^{2}=0.834
$$

where:

PCM is the percentage change in the median entering mark,

PCA is the percentage change in the number of applications,

$\mathrm{PCR}$ is the percentage change in the number of first year registrants and

$\mathrm{R}^{2}$ is the coefficient of determination (equal to the square of the correlation coefficient), which measures the proportion of the variance of the dependent variable that is explained by the independent variable.

This equation shows that 83 percent of the changes in median entering marks for the various programs are explained by changes in the number of applicants to these programs and in the number of available spaces in each program. In particular, the coefficient of the independent variable implies that the median entering average in a program increases by 1 when the number of applications to that program grows by $6.5 \%$ more than the number of available spaces for first-year students. ${ }^{18}$

The residual change in entering marks is explained by other factors, including changes in the marks of applicants. For example, registrations in both the commerce and engineering programs rose by approximately $26 \%$ more than applications to those programs during the period under consideration. Ceteris paribus, this should have lowered the median entering average by an estimated 4 points from 1984 to 1993 . Since the actual median average in the commerce program increased by 2 (from 77 to 79), we can infer that applicants' grades were inflated by 6 points. In contrast, grades for applicants to the engineering program rose by 4 , exactly offsetting the decline in the median entering average resulting from the more rapid growth in registrations than in applications. The differential rates of grade inflation across programs can, in turn, be linked to different program admission prerequisites. ${ }^{19}$

A similar OLS regression shows that the cutoff entering mark would rise by 1 when the growth in applications exceeds that in available spaces by $5.5 \%$ :

$$
\begin{aligned}
\mathrm{PCC}= & \underset{(55.604)}{0.074}+0.181(\mathrm{PCA}-\mathrm{PCR}), \quad \mathrm{R}^{2}=0.732
\end{aligned}
$$

where $\mathrm{PCC}$ is the percentage change in the cutoff entering mark. 
Figures $3 \mathrm{~A}$ and $3 \mathrm{~B}$ present similar data for each university. The picture here stands in sharp contrast to our earlier results: the cutoff entering average mark was unchanged at one university and rose in the remaining 14 institutions by a weighted average of 6.1 points, although the system-wide increase was only $4 .^{20}$ Similarly, the weighted average change in the mean entering marks was 3.7 while the system-wide increase was only 2.6 . These disparities illustrate Simpson's paradox which states that the average value of a variable for a population may change more or less (or even in the opposite direction) than the value for all subgroups if the proportions represented by these subgroups change. For example, assume that over a period of time the proportion of females in school A declines from $30 \%$ to $25 \%$ while its student population increases from 100 to 120 . At the same time, the proportion of female students in school B also declines from 70 to $65 \%$ while its student body grows from 100 to 280 . For the two schools combined, female representation would have increased from $50 \%$ to $53 \% .^{21}$

In our case, the increase in available spaces at universities with higher admission standards resulted in a rapid escalation of their cutoff marks. As students were diverted to the remaining universities, the higher-than-average growth rates in applications rapidly pushed up their entering marks as well. This is confirmed by the fact that if universities are ranked in descending order of their median entering marks in 1993, each of the top eight (Queen's, Waterloo, Toronto, McMaster, Guelph, Wilfrid Laurier, Western and Trent) had a smaller share of the total first-year enrolment in 1993 compared to 1983, while each of the remaining seven (Ottawa, Brock, Windsor, York, Lakehead, Laurentian and Carleton) increased its share. Within this framework, individual variations in cutoff, median and mean entering marks can be linked to changes in the number of applications, the number of admissions and grade inflation for applicants to each university.

\section{CONCLUSION}

The data we have presented do not lend support to the perception of rapidly escalating university admission standards in response to or as a cause of grade inflation at the high school level. Many of the changes that have occurred since the early 1980s can be exp̄lained in terms of demographic and behavioural changes affecting the number of secondary school applicants as well as in terms of political and economic forces that determine how many students are admitted into the university system. On this basis, we could anticipate that entering averages will show an accelerating upward trend as universities confront a sombre 
Figure 3A

Cutoff Entering Averages by University, 1983-1993.

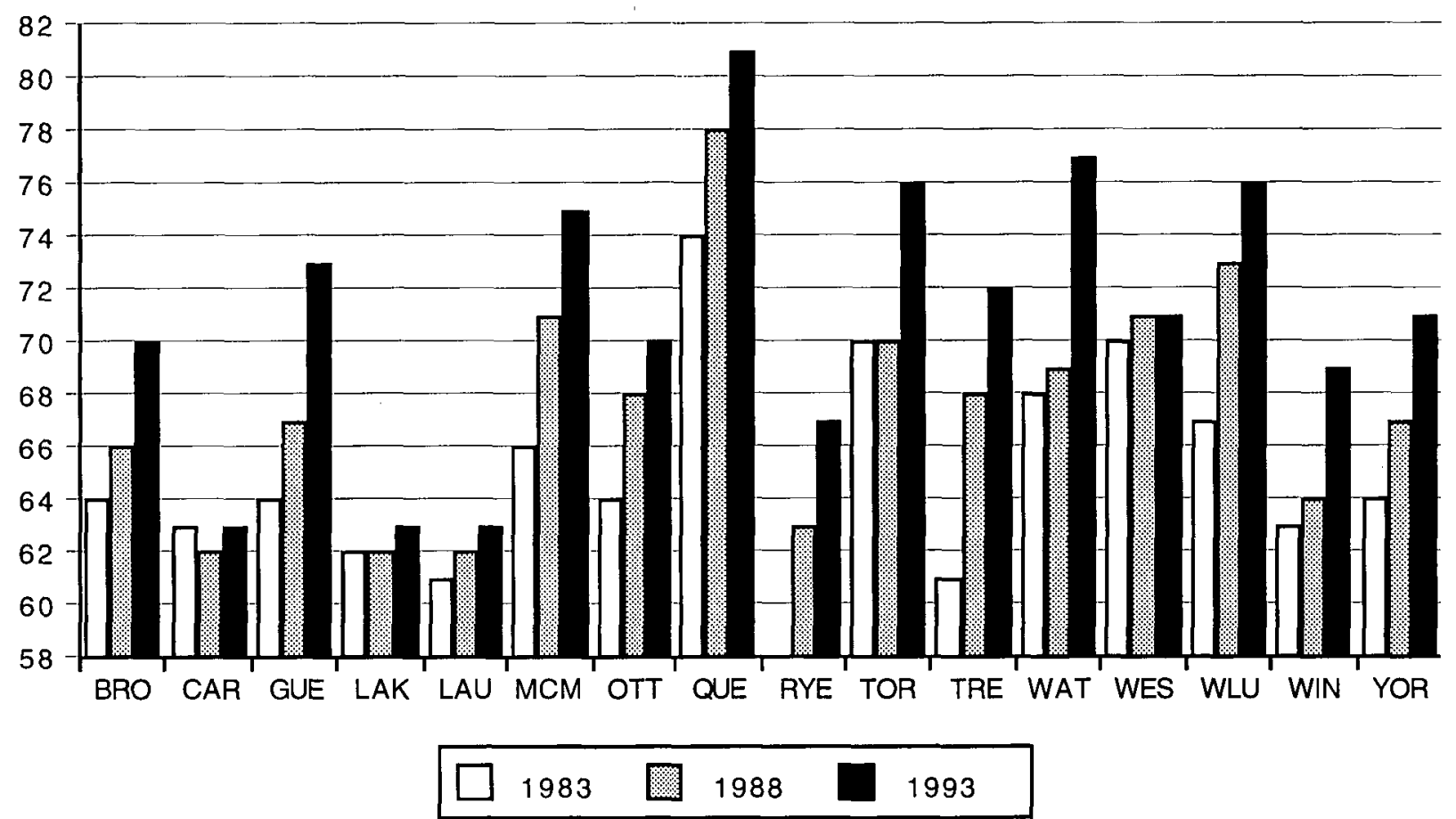

Source: Council of Ontario Universities, Entering Grade 13 Averages (various years) 


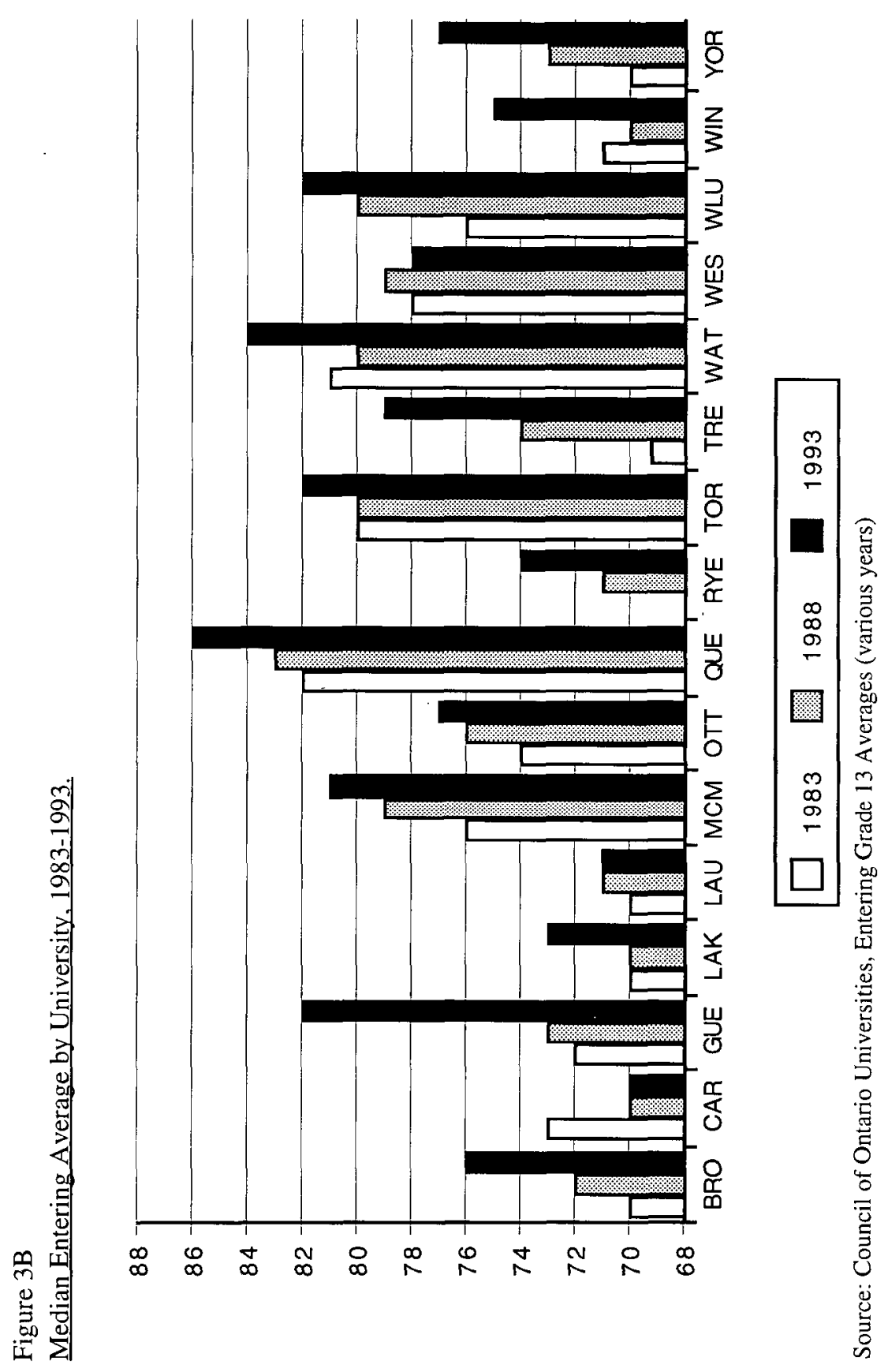


financial outlook and respond to their deteriorating budgetary conditions by restricting their annual student intake, although this upward trend may be mitigated by the slowdown in the growth of applications.

Many Ontario teenagers may be unnecessarily prolonging their stay in high school and/or resorting to various strategies that may ultimately be self-defeating or wasteful as these students respond to erroneous signals. Meaghan and Casas (1995a) have documented the fact that while the introduction of OACs to replace grade 13 was expected to substantially increase the proportion of students graduating in twelve years, the percentage of 18 year-old secondary school applicants declined substantially from 14.8 to 9.2 between 1980 and 1993, while the proportion of twenty-year old applicants rose from $10.2 \%$ to $15.7 \%$ during the same period. We believe these facts need to be presented and their implications discussed to prevent rumours and false perceptions from adversely impacting on students and schools. Universities also need to become more sensitive to the impact of their admission policies on secondary schools. Proposed changes such as the use of school rankings (Casas \& Meaghan, 1996b) and standardized test scores, automatic discounting of marks in repeated courses and increased weights for specific subjects in the admission average may enable universities to improve the selection process in the short run but may prove detrimental in the longer term as students and schools adjust to these changes.

\section{References}

Anderson, G.A., Benjamin, H.D., \& Fuss, M.A. (1994). The determinants of success in university introductory economics courses. Journal of Economic Education 25, 99-121.

Bejar, I.I., \& Blew, E.O. (1981). Grade inflation and the validity of the scholastic aptitude test. American Educational Research Journal, 18, 143-56.

Bracey, G.W. (1991). Why can't they be like we were? Phi Delta Kappan 73, 104-17.

Bromley, D.G., Crow, M.L., \& Gibson, M.S. (1978). Grade inflation, trends, causes and implications. Phi Delta Kappan, 59, 694-7.

Casas, F.R. (1994, January 10). Larger than life. University of Toronto Bulletin, 8.

Casas, F.R. (1995). Ontario's universities: Retrospective and trends - Secondary school applicants, 1973-1994. Report prepared for the Office of the Vice-Provost and Assistant Vice-President (Planning and Budget), University of Toronto.

Casas, F.R., \& Meaghan, D.E. (1995a). The impact of university admission practices on student achievement levels. Unpublished manuscript.

Casas, F.R., \& Meaghan, D.E. (1995b). Upgrading and the aging of the student population. Unpublished manuscript.

Casas, F.R., \& Meaghan, D.E. (1996a). If at first you don't succeed ... A study of course repeats among secondary school students in Ontario. The Journal of Educational Research, forthcoming. 
Casas, F.R., \& Meaghan, D.E. (1996b). School rankings in university admissions in Ontario: A choice between efficiency and equity? Higher Education Review, forthcoming.

Cawsey, K. (1993, April). Crunch is over for OAC students. Kitchener-Waterloo Record,

Cole, W. (1993, January 6). By rewarding mediocrity we discourage excellence. The Chronicle of Higher Education, B1-2.

Council of Ontario Universities. (1993). Brief to the Royal Commission on Learning. Toronto: Council of Ontario Universities.

Council of Ontario Universities. (various years). Entering averages of grade 13 registered applicants. Toronto: Council of Ontario Universities.

Council of Ontario Universities. (various years). Application statistics. Toronto: Council of Ontario Universities.

Crawford, T. (1993, October 9). Education 'grazing' under fire: Desperate high school students repeat courses to boost marks. The Toronto Star, A1-2.

Crouse, J., \& Trusheim, D. (1988). The case against the SAT. Chicago: The University of Chicago Press.

Daly, R. (1994, September 28). School moving to global system. The Toronto Star, A1.

Granger, B.G. (1994). What is grade 14? INFO, 46, 19-20.

Earnshaw, J. (1994). Notes on grade 13/OAC averages of Year 1 university registrants. INFO, 46, 24-26.

Jacobson, R.L. (1993, March 24). Critics say Graduate Record Exam does not measure qualities needed for success and is often misused. The Chronicle of Higher Education, A27-8.

King, A.J.C., \& Peirt, M.J. (1994). The numbers game. Toronto: Ontario Secondary School Teachers' Federation.

Meaghan, D.E., \& Casas, F.R. (1995a). Grade 14: Some comments on its incidence and effectiveness. INFO, 48, 64-72.

Meaghan, D.E., \& Casas, F.R. (1995b). On the testing of standards and standardized testing: Panacea, placebo or pandora's box? Interchange, 26, 33-58.

Ministry of Education (1984). Ontario schools: Intermediate and senior Divisions (Grades 7-12/OACs) program and diploma requirements 1984. Ontario: Ministry of Education.

Owen, D. (1985). None of the above: Behind the myth of scholastic aptitude. Boston: Houghton Mifflin.

Potter, W.P. (1979). Grade inflation: Unmasking the scourge of the seventies. College and University, 55, 19-26.

Rosser, P. (1989). The SAT gender gap. Washington: Center for Women Policy Studies.

Salvatore, D. (1994). Microeconomics. New York: Harper Collins.

Sandia National Laboratories (1993). Perspectives on education in America: An annotated briefing. The Journal of Educational Research, 86, 258-88.

Trow, M. (1977, May). American higher education, 1969-1975. The Chronicle of Higher Education., 1

Wegman, J.R. (1987). An economic analysis of grade inflation using indexing. College and University, 62, 137-46. 


\section{Notes}

1 Under the directives of the 1984 Ministry of Education circular Ontario Schools: Intermediate and Senior Divisions (OSIS), the requirements for the Ontario Secondary School Diploma (OSSD) were set at a minimum of 30 full-year credits beginning in grade 9 , including 16 compulsory and 14 elective credits. While five grade levels are offered in several subjects, students taking a full course load of 8 credits each year can complete the OSSD requirements by the end of grade 12 - a practice incongruously described as fasttracking. Courses offered at the most advanced level - replacing the grade 13 credits - are designated as Ontario Academic Courses (OACs) and while no OAC is prescribed for the OSSD, 6 OACs are required for admission to university. When a student completes more than 6 OACs, the average of the six highest marks is used for university application purposes.

2 While some of these practices have been described in media reports (see, for example, Crawford, 1993), there has not yet been a systematic effort to document or quantify them. The terminology used here is offered to help organize the discussion on this issue.

3 Since only the highest mark is retained in the student record, there is no penalty for repeating. The incidence and effects of OAC repeats are investigated in Casas and Meaghan (1996a).

4 Reminiscing about her last year in high school, Wilfrid Laurier University freshman Kathleen Cawsey (1993) recalls that "after April 15, nothing mattered. Time was up, the verdict was set in stone, judgement passed. Now all we have to do is wait for June - when we find out who made heaven, and who's in hell." In a recent study, Casas and Meaghan (1995a) found that the slumping effect as measured by the discrepancy between interim and final marks was consistently larger for males than for females and in science and mathematics compared to languages and social sciences.

5 See Casas and Meaghan, 1995b.

6 Similarly, in justifying why the proportion of students graduating from Upper Canada College - an elite Toronto private school - with an average higher than $80 \%$ has nearly quintupled from $12.9 \%$ to $71.9 \%$ between 1966 and 1992, the school's Vice-President, V. Mould, complained that the "whole system has been jacked up." See Daly, 1994.

7 For example, Bejar and Blew (1981) showed that freshman GPAs are more strongly correlated with high school records than with SAT scores. Owen (1985) has also noted that SAT scores are not strongly correlated with first-year university marks but that they are good predictors of marks in another standardized test, the Graduate Record Examination (GRE)! As reported by Jacobson (1993), a USC study found no significant difference in Ph.D. attainment rates between students with relatively high GRE scores and those with low scores.

8 In a six-year study, Crouse and Trusheim (1988) showed that the SAT has an adverse effect on black and low-income applicants for university admission while Rosser (1989) reported that the SAT is biased against women, underpredicting their grades at the postsecondary level. Many of the arguments in the recently renewed debate over standardized testing are surveyed in Meaghan and Casas (1995b). In a recent study, Anderson, 
Benjamin and Fuss (1994) found that the best predictor of student performance in introductory Economics is the overall achievement level in high school and they noted that "there are no uniform entrance examinations such as SATs in Ontario, and the variation in quality of instruction and grading practices across high schools might be expected to insert substantial noise into the relationship between performance in high school and performance in introductory university courses ... This presumption is apparently untrue."

9 The implicit cost - in the form of foregone lifetime earnings - of spending an additional year in high school may well be a stronger disincentive to students from lower economic strata, although this may be offset by the higher expected earnings associated with a university degree (or a degree from a more prestigious university or in a more marketable discipline).

10 In its report to the Ontario Royal Commission on Learning, the Council of Ontario Universities (1993) expressed concern about this possibility but did not examine whether university admission requirements had indeed been rising. The brief did refer to a rise in the proportion of Ontario Scholars (graduates with $80 \%$ or more) among secondary school graduates between 1983 and 1992 as evidence of grade inflation in high schools, but this statistic uses an arbitrary criterion and is consequently inadequate to reflect the overall performance or quality of the various cohorts of graduates. This is especially the case because the very low percentage of university registrants with an average of 79 and the unexpectedly large proportion with an average of 80 clearly indicate that considerable grade adjustments occur in that range, thereby inflating the number of Ontario scholars with little impact on average high school grades or their distribution.

11 King and Peirt (1994) also found that marks awarded in night and summer school were consistent with those in regular day programs and that averages for students in separate (Catholic) schools were similar to those for public school graduates.

12 For example, Trow (1977) found that the percentage of students with a B+average in a national sample had doubled from 18 to 36 between 1969 and 1975 . See also Potter 1979.

13 Detailed and comprehensive data on secondary school university applicants and registrants in Ontario from 1973 to 1994 are found in Casas (1995).

14 What is commonly described as the cutoff point does not, in fact, refer to the lowest average mark for all students admitted into a university or a program but rather to a standard set by each university (or by individual programs or faculties within a university) for automatic admission. However, each university also sets aside a small proportion of its first year admissions for special cases and for candidates whose marks fall within a discretionary range below the cutoff mark (for such candidates, factors other than marks are taken into consideration). Thus, a university may decide that setting a minimum mark of 72 will attract a sufficient number of applicants (taking into account the proportion of students who decline offers of admission) to fill, say, 90 percent of the available spaces.

15 The approach used here is similar to the construction of grade indices discussed by Wegman (1987). Implicit in our analysis is the assumption that the population of first year registrants closely mirrors the population of applicants above the cutoff point. On 
the other hand, students admitted below the cutoff point constitute a small proportion of the applicant pool and are not selected on the basis of their entering marks.

16 Each applicant is allowed a maximum of three choices of programs at one or more universities and the larger increase in the overall number of applications resulted from the average number of choices per applicant rising from 2.84 in 1983 to 2.94 in 1993.

17 For arts and for science, the changes were computed over the 1984-93 period as the University of Toronto data for 1983 did not differentiate between these two programs.

18 The t-statistic for the coefficient of (PCA - PCR) shows that it is significant at the $99.5 \%$ level of confidence. Using changes in applications (PCA) and in registrations (PCR) as separate independent variables in the regression did not improve the fit significantly, raising the $R_{2}$ very marginally to 0.839 .

19 For example, applicants to the commerce program at the University of Toronto must complete OACs in English, calculus and one other mathematics course, while the engineering program requires English, calculus, algebra, physics and chemistry.

20 Ryerson Polytechnic was not included as figures from that institution were not reported until 1989. The weights used to calculate the average increase in the cutoff mark were the number of registrants at each university in 1983. Readers familiar with price indices will recognize that this procedure is equivalent to the construction of a Laspeyres index which overestimates the true change in a variable; using the 19.93 registrant figures yields a Paasche-like underestimate of 5.7 for the average increase in the cutoff mark for the 15 universities. For a discussion of Laspeyres and Paasche indices, see Salvatore (1994, pp. 114-117).

21 A more dramatic example of Simpson's paradox was the fact that during the 1980 s, every ethnic or racial population in the U.S. maintained or improved its average SAT score but the combined average score declined during the same period. As demonstrated in a report prepared for the Sandia National Laboratories (1993), the decline in the average score did not reflect decreasing student performance but the fact that more students in the bottom half of their classes were taking the SAT than in earlier years. 